\title{
The Impact of RMB Exchange Rate Fluctuation on Price Level in China: An Empirical Analysis Based on the Vector Error Correction Model
}

\author{
Songlijiang Pan $^{1}$ \\ ${ }^{1}$ School of Economics, East China Normal University, Shanghai, China \\ Correspondence: Songlijiang Pan, School of Economics, East China Normal University, Shanghai, 200062, \\ China. Tel: 1-86-18217237970. E-mail: songlijiang.pan@foxmail.com
}

Received: March 16, 2018

Accepted: March 28, 2018

Online Published: April 15, 2018

doi:10.5539/ijef.v10n5p184

URL: https://doi.org/10.5539/ijef.v10n5p184

\begin{abstract}
With the improvement of RMB internationalization level, the impact of the changing international financial environment on China's economy is becoming more and more serious, so it is increasingly important to study the transfer effect of exchange rate changing on Chinese prices. Based on the monthly data from August 2005 to October 2016 and by constructing vector error correction model, this paper empirically examines the transfer effect of RMB exchange rate changes on China's price level. It is found that: 1) The transfer effect of nominal effective exchange rate of RMB on the single price index is smooth. 2) The transfer effect of RMB nominal effective exchange rate on China's price index is incomplete and there is a certain delay. For each unit of appreciation of RMB, the consumer price index will fall by 0.18 units. Import price index (IPI) respond most quickly to exchange rate movements, while producer price index (PPI) and consumer price index (CPI) slow down in turn. 3) The error correction model analysis shows that the nominal effective exchange rate of RMB has a certain self-correcting mechanism for the transfer effect of China's price index.
\end{abstract}

Keywords: exchange rate, pass-through mechanism, price level, vector error correction model

\section{Introduction}

In the early 1970s, the Bretton Woods system collapsed. The fixed exchange rate system was gradually replaced by the floating exchange rate system. Whether changes of the exchange rate would affect the price level of a country, whether exchange rate fluctuation would be completely transmitted to the price level of a country, these questions have aroused wide attention from academic circles. As the volatility of the world's major currencies continues to increase, fluctuation of exchange rates have affected all aspects of financial markets and the real economy in various countries. The researchers used a lot of empirical research using data from developed countries and the results showed that the exchange rate pass-through was incomplete. Subsequent research extended the sample to emerging countries and developing countries, but the conclusion also indicated that the degree of transmission was incomplete. Research on the impact of exchange rate fluctuation on the price level of a country, that is, the issue of "exchange rate-price level" transmission, is a worldwide research topic. Facing with frequent occurrence of financial crisis and the continuous continuation of inflation, people pay more attention to this research topic nowadays.

RMB officially joined the SDR in October of 2016 to become the world's reserve currency, the fluctuation of exchange rate of RMB increasingly becomes an important issue concerned by scholars at home and abroad. Although there has been a long history of research on this topic, there is still a lack of empirical research on the effect of changes in the exchange rate of the RMB on China's price level. Existing studies have also focused on the transfer of RMB exchange rates on China's export prices, there is still relatively rare empirical analysis of the impact of fluctuation of the exchange rate of RMB on China's price level. If the fluctuation of the exchange rate of RMB does have an impact on the price level in China, it would be useful to consider the magnitude of this impact when formulating monetary policy and considering the effectiveness of monetary policy. Therefore, it is of great theoretical and practical significance to study the impact of RMB exchange rate fluctuation on China's price level. 


\section{Literature Review}

Early empirical analysis of the "exchange rate-price level" pass-through effect have adopted the single equation regression method. They mainly use single-equation regression to examine whether firms have "pricing to market" behavior and the impact of exchange rate fluctuation on the import price, these import price mainly including overall import prices and import prices of various industries. Most studies have shown that exchange rate changes do not fully pass to import prices, and there is still a certain time lag in the transfer. At the same time, some researchers have found that there are significant differences in the exchange rate transfer ratio of different countries' import prices. These studies, such as Feenstra (1989) and Marston (1990), adopted the additive pricing model and estimated the impact of exchange rate fluctuation on import prices and consumer prices through a single equation regression method. Sekine (2006) used a single-equation stochastic volatility model with parameters that changed over time to estimate the conduction effects of exchange rates in the first and second phases of the six major industrialized countries, respectively. Marazzi and Sheets (2007) also used a rolling regression method to test the effect of changes in the exchange rate of the U.S. dollar on the import price based on the traditional mark-up model.

However, research on the transfer effect of exchange rate on domestic price level should be studied in conjunction with macroeconomic background. In consideration of the macroeconomic background, single-equation regression has been unable to deal with multivariate problems. Therefore, empirical studies have begun to adopt the vector autoregressive (VAR) method that takes into account the characteristics of the time series of variables and the inter-variable endogeneity. Consider the single-equation regression of the time series properties of the variables. The VAR model has significant advantages in measuring the exchange rate conduction effect and so on. It has been widely used by many scholars, and on the basis of the VAR model, many variants of this method have been developed, such as the vector error correction model (VECM).

Kim (1998) used the cointegration and vector error correction model (VECM) to estimate the transfer coefficient of the exchange rate fluctuation of the United States. He studied the transfer effect of the effective exchange rate of the U.S. dollar on producer prices in the U.S., and also included the variables such as money supply, gross national income and interest rates. He finally founds that the change in the exchange rate of the US dollar significantly affected the producer price in the United States. In addition, McCarthy (2000), Hahn (2003), and Faruqee (2004) also used the VAR method to analyze the impact of several shocks on the price level of different countries. They used Cholesky decomposition to sort variables to identify structural shocks. After that, the impulse response function and variance decomposition method were used to study the transmission effects of various shocks on the inflation rate in many countries. Yongxiang (2001) is the earliest Chinese scholar to use empirical research methods to study the effect of exchange rate changes on price. He used the error correction model (ECM) to research the impact of the nominal effective exchange rate of RMB change to retail prices and producer prices in China. Since then, Wei et al. (2009), Hailin (2010), Jun and Xiaosen (2011) and others have also adopted the VAR model to study the RMB exchange rate transfer effect from different perspectives.

In recent years, the scholars' research on the exchange rate transfer effect has expanded to various aspects. An and Wang (2012) used the VAR model to study the effects of exchange rates on import prices index (IPI), producer prices index (PPI), and consumer price index (CPI) in nine OECD countries. Ghosh (2013) studied the transmission of exchange rate to import prices and consumer prices in nine Latin American countries from 1970 to 2010, and believes that the exchange rate transmission effect continues to decline. Guoming \& Qingfang (2014) studied this issue from the perspective of changes of the exchange rate system and founds that the exchange rate fluctuations have a weaker effect on price levels, and exchange rate fluctuations have different effects on the transmission effects of various price indices. Auer (2015) analyzed the reform of the RMB exchange rate from 2005 to 2008 and believed that the competitive environment the company is facing will also affect the transfer effect of exchange rates on domestic prices. Sheng and Tao (2015) adopted a binary VAR-GARCH $(1,1)$-BEKK model to empirically analyze the correlation between exchange rate changes and CPI changes from the mean and volatility levels. Razafindrabe (2016) used the DSGE model to study the effect of the exchange rate in the euro zone. This study have shown that exchange rate shocks have a large impact on import prices.

The government's primary goal is to maintain the value of money a certain degree of stability. With the increasing internationalization of the RMB, the Chinese government has found that the impact of the global financial market on the Chinese market is greater and more difficult to control than ever. With the acceleration of RMB internationalization, especially in the context of the RMB's participation in the SDR (Specific Drawing Rights), a lot of research on this issue occurred. Liang (2016) point out that the small fluctuation of exchange rate has little influence on China's economic, but the large fluctuation of exchange rate will have a severe 
impact.

Looking at the above research literature, China's exchange rate transmission effect is similar to that of most countries in the world and it is incompletely transmitted. In addition, the previous studies have less involved macroeconomic factors at the same time into the analysis model of the "exchange rate-price level" transmission effect. Therefore, on the basis of empirical studies on the "exchange rate-price level" transmission, this paper uses monthly data to construct a VECM model, and incorporates macro factors such as currency shocks, supply shocks, and demand shocks into the model to test the impact of exchange rate fluctuation on import prices, producer prices and consumer prices.

\section{Empirical Models and Data}

\subsection{Empirical Models}

There are many empirical models for studying the "exchange rate-price level" transmission effect. Most of them use the general equation proposed by Goldberg and Knetter (1997) to study the effects of exchange rate changes on domestic price transmission:

$$
P_{t}=\alpha+\delta X_{t}+\gamma \mathrm{E}_{t}+\lambda \mathrm{Z}_{t}+\varepsilon_{t}
$$

Where $P_{t}$ indicates the domestic price level; $X_{t}$ is a control variable that describes the foreign situation, such as the price or cost of foreign exporters; $E_{t}$ indicates the nominal effective exchange rate of national currency; $\mathrm{Z}_{t}$ indicates a set of control variable of domestic which related to the economic growth of the country, such as the money supply, the gross domestic product, and so on.

Based on the McCarthy (2000) model and the general equations of Goldberg and Knetter (1997), we set the following basic empirical equations:

$$
\ln Y_{t}=\beta_{1}+\beta_{2} \ln W C P I_{t}+\beta_{3} \ln G D P_{t}+\beta_{4} \ln N E E R_{t}+\beta_{5} \ln M 1_{t}+\varepsilon_{t}
$$

Where $\ln Y_{t}$ indicates the price level in China, it is one of price indices. $\ln W C P I_{t}, \ln G D P_{t}, \ln N E E R_{t}, \ln M 1_{t}$ represent the natural logarithmic form of the variables $W C P I_{t}, G D P_{t}, N E E R_{t}$, and $M 1_{t}$, respectively. If we corresponds the model (2) to the general equation (1), we can see the control variables $X_{t}$, which describing the foreign situation, representing international price levels; The variables sets $Z_{t}$ means the control variables for domestic situation, it includes the money supply and GDP, which respectively represent the supply and demand of a country, are used to measure domestic macroeconomic conditions.

\subsection{Data}

This paper selected monthly data from August 2005 to October 2016 as a sample of the study. The reason why we selected the data after August 2005 is because on July 21, 2005, China implemented the reform of the exchange rate system and improved the RMB exchange rate formation mechanism. The RMB exchange rate is no longer solely pegged to the US dollar, but rather it is pegged to a number of major currencies. The composition of the currency basket to achieve a managed floating exchange rate system. Under this system, the RMB exchange rate should be calculated with reference to a basket of currencies to calculate the RMB's multilateral exchange rate index. Therefore, starting in August 2005, China's exchange rate fluctuations have significantly increased. At the same time, selecting the monthly data after August 2005 as a sample of the study can avoid the problem of inconsistency in the analysis of data before and after analysis.

There are many domestic price indexes. This paper selects the import price index (IPI), producer price index (PPI), and consumer price index (CPI) to represent the overall price level of China. Therefore, the transfer effect of the definition of exchange rate changes on domestic prices is: When the RMB exchange rate changes by one unit $(1 \%)$, the percentage change of the price index (IPI, PPI, CPI).

The following seven research indicators are selected in this paper. The statistics of each variable description are shown in Table 1:

The nominal effective exchange rate of RMB (NEER). This indicator adopts the indirect quotation method. Under this quotation method, if the nominal effective exchange rate of RMB rises, the RMB will appreciate. If the nominal effective exchange rate of RMB decreases, the RMB will depreciate. The data comes from the Bank for International Settlements (BIS). This paper converts the data to base on August 2005 as the base period.

Currency supply. There are many kinds of money supply indicators. This paper adopts the narrowly defined money supply (M1) issued by the People's Bank of China. This indicator more reflects the money demand for trading and is more closely linked with price.

Import price index (IPI). The import price index reflects the overall price level of China's imports, and is the 
most direct channel through which exchange rate fluctuations affect domestic general price. China's import price index has been counted and announced by the General Administration of Customs since 2005. This paper uses the import price index published by the General Administration of Customs and calculates the import price index based on August 2005.

Gross domestic product (GDP). Because China does not publish monthly data on GDP, this paper uses the "industrial added value" method to approximate the monthly GDP. After that, we converts it to the base period of August 2005 through the corresponding GDP deflator. This indicator comes from the National Bureau of Statistics of China, and the author calculate it into monthly data. It is used to reflect the demand of China.

Consumer price index (CPI). This index is an index reflecting the overall price level and the extent of change of goods and services that residents use to purchase and consume. It is closely related to people's daily life and can reflect the changes in the consumer market price more comprehensively. This indicator comes from the National Bureau of Statistics of China. The index is based on August 2005.

The World Commodity Price Index (WCPI), which measures global commodity price levels and reflects external supply shocks, comes from the International Monetary Fund (IMF). The indicator is based on August 2005.

The producer price index (PPI), which measures the overall level and changing trend of the ex-factory prices of industrial producers, reflects the important economic indicators of price changes in the production sector over a period of time. This data comes from the National Bureau of Statistics of China. The indicator is based on August 2005.

These data except for money supply is adjusted and converted to time series data based on August 2005. In order to eliminate seasonal factors, the Census X12 method is used to seasonally adjust all data. In order to avoid the dramatic fluctuations and elimination of heteroskedasticity exist in the time series data, we take the natural logarithm of each variable, and the variables are: $\ln N E E R, \ln M 1, \ln I P I, \ln G D P, \ln C P I, \ln W C P I$, and $\ln P P I$.

All the empirical tests in this paper are analyzed using Eviews 7.2 econometrics software.

Table 1. Descriptive statistics of the full sample

\begin{tabular}{cccccccc}
\hline & $\ln C P I$ & $\ln G D P$ & $\operatorname{lnIPI}$ & $\ln M 1$ & $\ln N E E R$ & $\ln P P I$ & $\ln W C P I$ \\
\hline Mean & 4.800180 & 10.17720 & 4.872430 & 12.27780 & 4.750106 & 4.707828 & 4.924149 \\
Median & 4.792444 & 10.21225 & 4.881289 & 12.42116 & 4.746615 & 4.717954 & 4.940928 \\
Maximum & 4.935192 & 10.56989 & 5.044718 & 12.84167 & 4.971367 & 4.791835 & 5.247665 \\
Min & 4.606661 & 9.625212 & 4.587771 & 11.50585 & 4.599690 & 4.598568 & 4.523778 \\
Standard deviation & 0.095646 & 0.261028 & 0.117584 & 0.404831 & 0.104699 & 0.052145 & 0.220044 \\
Skewness & -0.374605 & -0.311501 & -0.363650 & -0.454316 & 0.353102 & -0.271081 & -0.270866 \\
Kurtosis & 2.038490 & 1.973035 & 1.829421 & 1.776785 & 2.242967 & 1.966295 & 1.587479 \\
Jarque-Bera & 7.614811 & 7.394288 & 9.733502 & 11.89957 & 5.493086 & 6.982736 & 11.72954 \\
\hline
\end{tabular}

\section{Empirical Results}

This paper examines the impact of the RMB exchange rate fluctuation on domestic general price in the following three steps: First, test the stability of the relevant variables; second, test the long-term cointegration relationship between variables, if there is a long-term cointegration relationship, the cointegration equation is derived. In the third step, based on cointegration test results, it is determined whether vector error correction model is used to test the conduction effect of RMB exchange rate on different price indexes.

\subsection{Stationarity Test}

There are many methods to test the stationarity of a time series. In this paper, what we used are ADF test (Augmented Dickey-Fuller) and PP test (Phillips-Perron). The ADF test belongs to the left test in the unilateral test. If the statistic of the ADF test is greater than the critical value, the tested sequence is non-stationary. If the statistic of the ADF test is less than the critical value, the tested sequence is stable. The PP test also belongs to the left test in the unilateral test. The test method is similar. For the selection of the number of lag periods, reference is made to the Akaike info criterion (AIC) and the Schwarz criterion (SC).

This paper uses Eviews 7.2 software, using ADF test and PP test respectively, to test the natural logarithm of the seven variables. The specific test results are listed in Table 2.

From the results of the ADF test and the PP test, the test statistics for all indicators in this paper are greater than their corresponding critical values at the $1 \%$ significance level, rejecting the null hypothesis, indicating that all 
indicators are non-stationary. And their corresponding test statistics of the first-order difference are all smaller than their corresponding critical values, indicating that the first-order difference of all indicators is stable, that is, the original time series of the indicators is not stable, but the time series obtained after the first-order difference is stable, so all indicators are monotonous in the order of I (1). The results of the empirical test in this paper are in accordance with the previous experience theory.

Table 2. Unit root test results

\begin{tabular}{|c|c|c|c|c|c|c|c|}
\hline \multirow[b]{2}{*}{ Variables } & \multicolumn{3}{|c|}{ ADF inspection } & \multicolumn{3}{|c|}{ PP inspection } & \multirow[b]{2}{*}{ Conclusion } \\
\hline & $\begin{array}{l}\text { Inspection type } \\
(\mathrm{c}, \mathrm{t}, \mathrm{n})\end{array}$ & Statistics & $\begin{array}{c}\text { Critical } \\
\text { value (5\%) }\end{array}$ & $\begin{array}{l}\text { Inspection type } \\
(\mathrm{c}, \mathrm{t}, \mathrm{n})\end{array}$ & Statistics & $\begin{array}{c}\text { Critical value } \\
(5 \%)\end{array}$ & \\
\hline $\operatorname{lnCPI}$ & $(\mathrm{c}, \mathrm{t}, 3)$ & -1.9955 & -3.4480 & $(\mathrm{c}, \mathrm{t}, 7)$ & -1.7650 & -3.4471 & unstable \\
\hline$\Delta \operatorname{lnCPI}$ & $(\mathrm{c}, 0,2)$ & -4.2549 & -3.4480 & $(\mathrm{c}, 0,6)$ & -10.6202 & -3.4474 & stable \\
\hline $\operatorname{lnGDP}$ & $(\mathrm{c}, \mathrm{t}, 2)$ & -2.7426 & -3.4477 & $(\mathrm{c}, \mathrm{t}, 6)$ & -4.8447 & -3.4471 & unstable \\
\hline$\Delta \operatorname{lnGDP}$ & $(\mathrm{c}, 0,1)$ & -18.1647 & -3.4477 & $(\mathrm{c}, 0,1)$ & -18.4855 & -3.4474 & stable \\
\hline $\operatorname{lnIPI}$ & $(\mathrm{c}, \mathrm{t}, 0)$ & -1.4658 & -3.4471 & $(\mathrm{c}, \mathrm{t}, 6)$ & -1.8435 & -3.4471 & unstable \\
\hline$\Delta \operatorname{lnIPI}$ & $(\mathrm{c}, 0,0)$ & -12.1235 & -3.4474 & $(\mathrm{c}, 0,6)$ & -11.9968 & -3.4474 & stable \\
\hline $\operatorname{lnM} 1$ & $(\mathrm{c}, \mathrm{t}, 0)$ & -0.7572 & -3.4471 & $(\mathrm{c}, \mathrm{t}, 7)$ & -0.9161 & -3.4471 & unstable \\
\hline$\Delta \operatorname{lnM} 1$ & $(\mathrm{c}, 0,0)$ & -12.1387 & -3.4474 & $(\mathrm{c}, 0,7)$ & -12.1905 & -3.4474 & stable \\
\hline lnNEER & $(\mathrm{c}, \mathrm{t}, 3)$ & -3.0352 & -3.4480 & $(\mathrm{c}, \mathrm{t}, 6)$ & -2.3951 & -3.4471 & unstable \\
\hline$\triangle \operatorname{lnNEER}$ & $(\mathrm{c}, 0,1)$ & -7.4489 & -3.4477 & $(\mathrm{c}, 0,3)$ & -6.6405 & -3.4474 & stable \\
\hline $\operatorname{lnPPI}$ & $(\mathrm{c}, \mathrm{t}, 2)$ & -1.1025 & -3.4477 & $(\mathrm{c}, \mathrm{t}, 7)$ & -0.7817 & -3.4471 & unstable \\
\hline$\Delta \operatorname{lnPPI}$ & $(\mathrm{c}, 0,1)$ & -4.4131 & -3.4477 & $(\mathrm{c}, 0,4)$ & -3.9751 & -3.4474 & stable \\
\hline $\operatorname{lnWCPI}$ & $(\mathrm{c}, \mathrm{t}, 1)$ & -1.5129 & -3.4474 & $(\mathrm{c}, \mathrm{t}, 6)$ & -1.4126 & -3.4471 & unstable \\
\hline$\Delta \operatorname{lnWCPI}$ & $(\mathrm{c}, 0,0)$ & -7.0840 & -3.4474 & $(\mathrm{c}, 0,5)$ & -7.2562 & -3.4474 & stable \\
\hline
\end{tabular}

Note. $1, \Delta$ represents the first-order difference; $2, \mathrm{c}, \mathrm{t}, \mathrm{n}$ of the test type $(\mathrm{c}, \mathrm{t}, \mathrm{n})$ indicates the test has a constant term, the time trend terms and the lag used by the order, respectively. The lag order is automatically determined by Eviews according to the AIC, SC criteria.

\subsection{Johansen Cointegration Test}

Before establishing the vector error correction model (VECM), it is first necessary to verify whether there is a cointegration relationship among the variables, and only when there is a cointegration relationship exist that a vector error correction model (VECM) can be established. Engle and Granger (1987) pointed out that although some variables are not stable, but some of their linear combinations may be stable. This linear combination, which can explain long-term stable equilibrium between variables, is called cointegration equation. The cointegration test requires that the variables are single integer variables and that the single order number is the same. From the above stationarity test results, it is known that all the variables are all I (1)-order single integer variables, so there may be co-integration relationships and the variables in this paper need to be test.

According to the empirical research literature, the main cointegration test methods are EG two-step method and Johansen cointegration test method. EG two-step method is used earlier and more suitable for the co-integration test between two variables. The Johansen cointegration test is used recently, and it is not necessary to divide the variables into internal and exogenous variables during the test. It can simultaneously provide all the cointegration relations, and the effect is also more stable. According to empirical theory, the Johansen cointegration test method is generally used when the tested parameter is greater than two. Therefore, this paper uses Johansen cointegration test method to perform cointegration test on the variables.

\subsubsection{Cointegration Test on Import Price Index}

First, a cointegration test was performed on the basic model of the import price index as a dependent variable using a test model with intercept items and trend items. According to the AIC and SC criterion, reference to LR statistics, the optimal lag order of the unconstrained vector autoregressive model is determined to be 3 orders. Therefore, the lag order of the Johansen cointegration test is chosen to be 2 orders. The Johansen cointegration test results are shown in Table 3. The trace statistics and maximum eigenvalues in the test results show that at the $5 \%$ level of significance, there are two cointegration equations between the import price index, the nominal effective exchange rate of RMB, the gross domestic product, the global commodity price index, and the narrow money supply. 
Table 3. Cointegration test results on import price index

\begin{tabular}{cccccccc}
\hline \multirow{2}{*}{$\begin{array}{c}\text { Number of } \\
\text { cointegration equations }\end{array}$} & Trace statistics & \multicolumn{2}{c}{ Trace statistics threshold } & \multirow{2}{*}{$\begin{array}{c}\text { Maximum } \\
\text { eigenvalue }\end{array}$} & & \multicolumn{2}{c}{ Maximum eigenvalue statistics threshold } \\
\cline { 3 - 4 } No & $93.28245^{*}$ & 69.81889 & 0.0002 & $36.45945^{*}$ & 33.87687 & 0.0240 \\
Up to 1 & $56.82299^{*}$ & 47.85613 & 0.0058 & $35.12777^{*}$ & 27.58434 & 0.0045 \\
Up to 2 & 21.69523 & 29.79707 & 0.3158 & 15.94724 & 21.13162 & 0.2280 \\
Up to 3 & 5.747983 & 15.49471 & 0.7251 & 5.456664 & 14.26460 & 0.6834 \\
\hline
\end{tabular}

Note. ${ }^{*}$ means rejecting the null hypothesis at a $5 \%$ significance level, and the p-value represents MacKinnon-Haug-Michelis p-values.

The standardized cointegration equation is shown in formula (3). The cointegration equation shows that in the long run, the import price index is positively related to the global commodity price index and money supply, and negatively related to the gross domestic product and the nominal effective exchange rate of RMB. The nominal effective exchange rate of RMB has a negative impact on the import price. Specifically, a one-unit appreciation of the nominal effective exchange rate of the RMB will drive down the import price by 0.29 units. The money supply have a positive effect on the import price. For every additional unit of money supply, the import price will increase by 0.33 units.

$$
\ln I P I_{t}=-0.2869 \ln N E E R_{t}-0.2302 \ln G D P_{t}+0.2563 \ln W C P I_{t}+0.3337 \ln M 1_{t}
$$

\subsubsection{Cointegration Test on Producer Price Index}

Then, we using a test model with intercept items and trend items to perform a cointegration test on the basic model of the producer price index as a dependent variable. According to the AIC and SC criterion, reference to LR statistics, the optimal lag order of the unconstrained vector autoregressive model is determined to be 3 orders. Therefore, the lag order of the Johansen cointegration test is chosen to be 2 orders. The Johansen cointegration test results are shown in Table 4. The trace statistics and maximum eigenvalues in the test results indicate that at the $5 \%$ level of significance, between the producer price index, nominal effective exchange rate of RMB, gross domestic product, global commodity price index, and narrow money supply, there are two cointegration equations.

Table 4. Cointegration test results on producer price index

\begin{tabular}{|c|c|c|c|c|c|c|}
\hline \multirow{2}{*}{$\begin{array}{c}\text { Number of cointegration } \\
\text { equations }\end{array}$} & \multirow{2}{*}{$\begin{array}{c}\text { Trace } \\
\text { statistics }\end{array}$} & \multicolumn{2}{|c|}{ Trace statistics threshold } & \multirow{2}{*}{$\begin{array}{l}\text { Maximum } \\
\text { eigenvalue }\end{array}$} & \multicolumn{2}{|c|}{ Maximum eigenvalue statistics threshold } \\
\hline & & $5 \%$ & P-value & & $5 \%$ & P-value \\
\hline No & $88.78763^{*}$ & 69.81889 & 0.0008 & $35.92954^{*}$ & 33.87687 & 0.0281 \\
\hline Up to 1 & $52.85809^{*}$ & 47.85613 & 0.0158 & $30.56672^{*}$ & 27.58434 & 0.0201 \\
\hline Up to 2 & 22.29137 & 29.79707 & 0.2826 & 16.89363 & 21.13162 & 0.1771 \\
\hline Up to 3 & 5.397745 & 15.49471 & 0.7652 & 5.318177 & 14.26460 & 0.7013 \\
\hline
\end{tabular}

Note. ${ }^{*}$ means rejecting the null hypothesis at a 5\% significance level, and the p-value represents MacKinnon-Haug-Michelis p-values.

The standardized cointegration equation is shown in formula (4). The cointegration equation shows that in the long run, the producer price index is positively related to the country's GDP and the global commodity price index, and the nominal effective exchange rate of RMB and the money supply are negative related. Every one-unit increase in the nominal effective exchange rate of the RMB will drive the producer price index down by 0.78 units. Increasing the supply of money by one unit will drive the producer price index down by 0.81 units.

$$
\ln P P I_{t}=-0.7846 \ln N E E R_{t}+1.5623 \ln G D P_{t}+0.3724 \ln W C P I_{t}-0.8144 \ln M 1_{t}
$$

\subsubsection{Cointegration Test on Consumer Price Index}

Next, a cointegration test was performed on the basic model of the consumer price index as a dependent variable using a test model with intercept items and trend items. According to the AIC and SC criterion, reference to LR statistics, the optimal lag order of the unconstrained vector autoregressive model is determined to be 3 orders. Therefore, the lag order of the Johansen cointegration test is chosen to be 2 orders. The Johansen cointegration test results are shown in Table 5. The trace statistics and maximum eigenvalues in the test results indicate that at the $5 \%$ level of significance, there are two cointegration equations existed between the consumer price index, the nominal effective exchange rate of RMB, the gross domestic product, the global commodity price index, and the narrow money supply. 
Table 5. Cointegration test results on consumer price index

\begin{tabular}{cccccccc}
\hline \multirow{2}{*}{$\begin{array}{c}\text { Number of cointegration } \\
\text { equations }\end{array}$} & \multirow{2}{*}{$\begin{array}{c}\text { Trace } \\
\text { statistics }\end{array}$} & \multicolumn{2}{c}{ Trace statistics threshold } & & Maximum & & Maximum eigenvalue statistics threshold \\
& $104.1822^{*}$ & 69.81889 & 0.0000 & $51.03325^{*}$ & 33.87687 & 0.0002 \\
No & $53.14899^{*}$ & 47.85613 & 0.0147 & $32.69640^{*}$ & 27.58434 & 0.0101 \\
Up to 1 & 20.45259 & 29.79707 & 0.3927 & 13.33813 & 21.13162 & 0.4216 \\
Up to 2 & 7.114459 & 15.49471 & 0.5644 & 6.304432 & 14.26460 & 0.5745 \\
Up to 3 & & &
\end{tabular}

Note. ${ }^{~}$ means rejecting the null hypothesis at a 5\% significance level, and the p-value represents MacKinnon-Haug-Michelis p-values.

The standardized cointegration equation is shown in formula (5). The cointegration equation shows that in the long run, the consumer price index is positively correlated with the nominal effective exchange rate of RMB, the gross domestic product, and global commodity price index, while negatively correlated with the money supply. Every one-unit appreciation of the nominal effective exchange rate of RMB will drive consumer prices up by 0.28 units, every one-unit increase in money supply will drive down consumer prices by 0.17 units.

$$
\ln C P I_{t}=0.2832 \ln N E E R_{t}+0.4955 \ln G D P_{t}+0.137 \ln W C P I_{t}-0.1692 \ln M 1_{t}
$$

Based on the above analysis, we finds that there is a cointegration relationship between these three price indices and the nominal effective exchange rate of RMB, gross domestic product, global commodity price index, and narrow money supply. The empirical research results show that the pass-through of the exchange rate fluctuation to a single price index is smooth.

\subsection{Vector Error Correction Model}

Engle and Granger (1987) combined the cointegration and vector error correction models to create the vector error correction model (VECM). The general expression of VECM is:

$$
\Delta y_{t}=\alpha \beta^{\prime} y_{t-1}+\sum_{i=1}^{n} G_{i} \Delta y_{t-i}+e_{t}
$$

At the same time, equation (6) can also be expressed as:

$$
\Delta y_{t}=\alpha E C M_{t-1} \Sigma_{i=1}^{n} G_{i} \Delta y_{t-i}+e_{t}
$$

In formula (7), $E C M_{t-1}$ is an error correction term that represents the cointegration relationship between variables and it reflects the long-term equilibrium relationship between variables. $\Delta \mathrm{y}_{t}$ represents the short-term fluctuations of the current variable. Coefficient $\alpha$ reflects the adjustment efforts from the unbalanced state to the equilibrium state. Therefore, VECM can be used to examine the long-term and short-term relationships among various variables in the economic system, so as to analyze the transmission of exchange rate fluctuation to different price indices.

On the basis of Johansen cointegration test, we refers to AIC criteria, SC criteria, LR statistics and other criteria, we determine the optimal lag order of unconstrained vector autoregressive model is 3 orders. So the optimal lag order of the vector error correction model we established is 2 orders. There are two cointegration vectors between variables is setting when we building the model. In addition, the Jarque-Bera normality test shows that the residuals meet the normal distribution requirements. Moreover, the LM test shows that there is no autocorrelation in the model residuals, and ARCHLM tests show that there is no ARCH effect in the model residuals.

According to the regression results of Eviews 7.2, the expressions of the respective vector error correction models are obtained as follows:

$$
\begin{aligned}
& D(L N I P I)=-0.3911 \times E C M-0.2051 \times D(\operatorname{LNIPI}(-1))-0.1392 \times D(\operatorname{LNIPI}(-2)) \\
& +0.0917 \times D(\operatorname{LNIPI}(-3))+0.0722 \times D(\operatorname{LNNEER}(-1))+0.091 \times D(\operatorname{LNNEER}(-2)) \\
& +0.1804 \times D(\operatorname{LNNEER}(-3))-0.0514 \times D(\operatorname{LNGDP}(-1))-0.0407 \times D(\operatorname{LNGDP}(-2)) \\
& -0.0027 \times D(L N G D P(-3))+0.1195 \times D(L N W C P I(-1))+0.0065 \times D(L N W C P I(-2)) \\
& +0.0208 \times D(L N W C P I(-3))-0.0203 \times D(L N M 1(-1))+0.2701 \times D(L N M 1(-2)) \\
& +0.2816 \times D(L N M 1(-3))-0.0044
\end{aligned}
$$




$$
\begin{aligned}
& D(L N P P I)=-0.0555 \times E C M+0.4535 \times D(L N P P I(-1))+0.1666 \times D(L N P P I(-2)) \\
& -0.1269 \times D(\operatorname{LNPPI}(-3))-0.084 \times D(\operatorname{LNNEER}(-1))+0.0737 \times D(\operatorname{LNNEER}(-2)) \\
& -0.0323 \times D(\operatorname{LNNEER}(-3))-0.0356 \times D(\operatorname{LNGDP}(-1))-0.0383 \times D(\operatorname{LNGDP}(-2)) \\
& -0.036 \times D(L N G D P(-3))+0.0364 \times D(L N W C P I(-1))+0.0113 \times D(L N W C P I(-2)) \\
& -0.0091 \times D(L N W C P I(-3))-0.0008 \times D(L N M 1(-1))+0.0211 \times D(L N M 1(-2)) \\
& +0.0126 \times D(\operatorname{LNM} 1(-3))+0.0008 \\
& D(L N C P I)=-0.0413 \times E C M-0.0153 \times D(L N C P I(-1))-0.0309 \times D(L N C P I(-2)) \\
& +0.0329 \times D(\operatorname{LNCPI}(-3))-0.0671 \times D(\operatorname{LNNEER}(-1))+0.0703 \times D(\operatorname{LNNEER}(-2)) \\
& -0.0503 \times D(\operatorname{LNNEER}(-3))-0.0404 \times D(\operatorname{LNGDP}(-1))-0.0298 \times D(\operatorname{LNGDP}(-2)) \\
& -0.0296 \times D(L N G D P(-3))+0.0091 \times D(L N W C P I(-1))+0.0066 \times D(L N W C P I(-2)) \\
& -0.0003 \times D(L N W C P I(-3))+0.0973 \times D(L N M 1(-1))-0.0026 \times D(L N M 1(-2)) \\
& +0.0379 \times D(\operatorname{LNM} 1(-3))+0.00214
\end{aligned}
$$

In the formula (8), the error correction coefficient of the import price index is -0.3911 . In the formula (9), the error correction coefficient of the producer price index is -0.0555 , and in the formula (10), the error correction coefficient of the consumer price index is -0.0413 . We can see there is a self-correcting dynamic mechanism of the "exchange rate-price level" transfer effect of RMB ranging from short-term fluctuations to long-term equilibrium. It shows that there is a long-term equilibrium relationship of "exchange rate-price level" transfer effect, and it can spontaneously adjust to long-term equilibrium after short-term fluctuations occur. The error correction coefficients of the producer price index and the consumer price index are relatively small, which indicates that the short-term deviation from the long-term equilibrium correction is slower. If there is a negative impact of the exchange rate changes on the domestic price level, the error correction term will gradually weaken this effect and correct it to a long-term equilibrium in the following year (Note 1).

After establishing the error correction model, we integrate three price indices into the model. We hope to analyze the exchange rate fluctuation along the price chain in impulse response function analysis and variance decomposition.

\subsection{Impulse Response Function Based on Vector Error Correction Model}

We choice the generalized impulse analysis method established by Koop et al. (1996), Pesaran and Shin (1998) to start the analysis. Different from the traditional impulse response function method, the generalized impulse response function analysis method does not require the orthogonality of the impact. It has nothing to do with the sequential arrangement of the variables. So it provides a better solution to the orthogonality impact, and thus can provide a more robust conclusion.
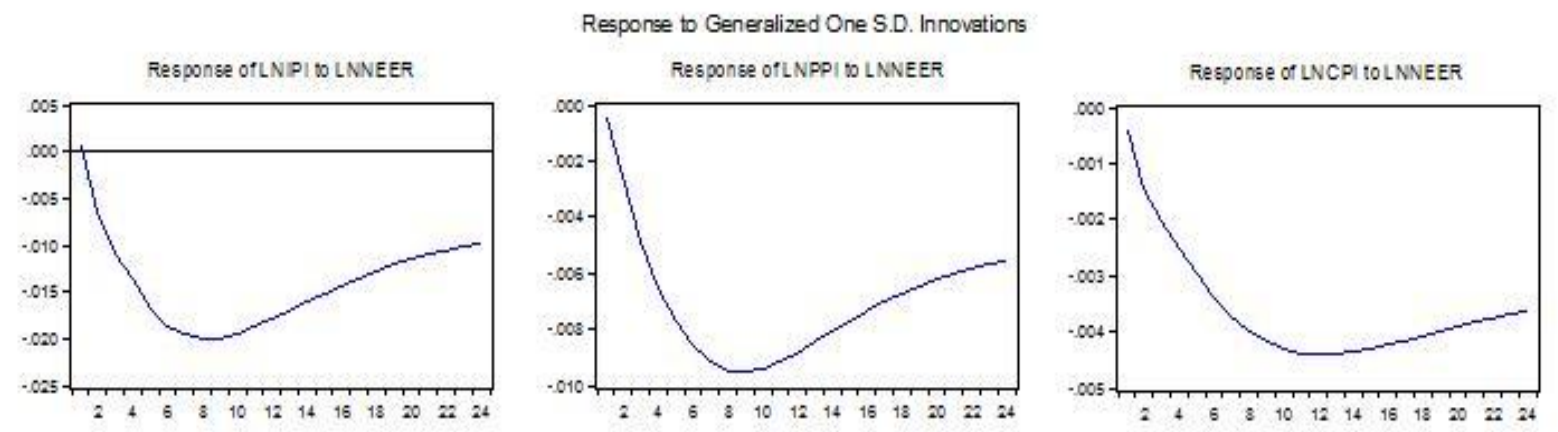

Figure 1. The impact of a standard differential exchange rate impact on all kinds of price index

Figure 1 shows the impact of a standard deviation shock of exchange rate on import prices, producer prices, and consumer prices, respectively. It can be seen that the three domestic price indexes all have negative reactions to the shock of the RMB exchange rate. The impact of the import price index on exchange rate shocks was the fastest among the three price indices and it reached the maximum in the eighth month after the impact: a decrease of 0.02 percentage points. The producer price index reacted to exchange rate shocks at a slower pace. It also reached a maximum in the eighth month after the shock: a decrease of 0.0095 percentage points. The 
consumer price index reflected the impact of exchange rate shocks the slowest and reached the maximum in the 11th month after the shock: a decrease of 0.0045 percentage points. Table 6 shows the transfer rate of domestic exchange rate for 1-36 months after the shock calculated by the cumulative impulse response function. It can be seen that the import price has the fastest response to the exchange rate shocks, and the producer price and consumer price response in turn slows down.

Table 6. Pass-through of NEER to domestic price

\begin{tabular}{|c|c|c|c|c|c|c|c|c|c|c|c|c|}
\hline period & 1 & 2 & 3 & 4 & 5 & 6 & 7 & 8 & 9 & 10 & 11 & 12 \\
\hline \multirow{5}{*}{$\operatorname{lnCPI}$} & 0.000 & 0.002 & 0.004 & 0.006 & 0.009 & 0.013 & 0.017 & 0.021 & 0.025 & 0.029 & 0.033 & 0.038 \\
\hline & 13 & 14 & 15 & 16 & 17 & 18 & 19 & 20 & 21 & 22 & 23 & 24 \\
\hline & 0.042 & 0.047 & 0.051 & 0.055 & 0.059 & 0.063 & 0.067 & 0.071 & 0.075 & 0.079 & 0.083 & 0.086 \\
\hline & 25 & 26 & 27 & 28 & 29 & 30 & 31 & 32 & 33 & 34 & 35 & 36 \\
\hline & 0.090 & 0.093 & 0.097 & 0.100 & 0.104 & 0.107 & 0.111 & 0.114 & 0.117 & 0.121 & 0.124 & 0.128 \\
\hline \multirow{6}{*}{$\operatorname{lnPPI}$} & 1 & 2 & 3 & 4 & 5 & 6 & 7 & 8 & 9 & 10 & 11 & 12 \\
\hline & 0.001 & 0.003 & 0.008 & 0.014 & 0.022 & 0.031 & 0.040 & 0.049 & 0.059 & 0.068 & 0.077 & 0.086 \\
\hline & 13 & 14 & 15 & 16 & 17 & 18 & 19 & 20 & 21 & 22 & 23 & 24 \\
\hline & 0.095 & 0.103 & 0.111 & 0.118 & 0.125 & 0.132 & 0.138 & 0.144 & 0.150 & 0.156 & 0.162 & 0.168 \\
\hline & 25 & 26 & 27 & 28 & 29 & 30 & 31 & 32 & 33 & 34 & 35 & 36 \\
\hline & 0.173 & 0.178 & 0.184 & 0.189 & 0.194 & 0.200 & 0.205 & 0.210 & 0.216 & 0.221 & 0.226 & 0.232 \\
\hline \multirow{6}{*}{$\operatorname{lnIPI}$} & 1 & 2 & 3 & 4 & 5 & 6 & 7 & 8 & 9 & 10 & 11 & 12 \\
\hline & 0.001 & 0.006 & 0.017 & 0.030 & 0.047 & 0.066 & 0.085 & 0.105 & 0.125 & 0.145 & 0.163 & 0.181 \\
\hline & 13 & 14 & 15 & 16 & 17 & 18 & 19 & 20 & 21 & 22 & 23 & 24 \\
\hline & 0.198 & 0.215 & 0.230 & 0.244 & 0.257 & 0.270 & 0.282 & 0.294 & 0.305 & 0.316 & 0.326 & 0.336 \\
\hline & 25 & 26 & 27 & 28 & 29 & 30 & 31 & 32 & 33 & 34 & 35 & 36 \\
\hline & 0.346 & 0.355 & 0.365 & 0.374 & 0.383 & 0.393 & 0.402 & 0.412 & 0.421 & 0.431 & 0.441 & 0.451 \\
\hline
\end{tabular}

As can be seen from Table 6, every $1 \%$ exchange rate appreciation in the sixth month will cause import prices, producer prices, and consumer prices to fall by $0.066 \%, 0.031 \%$, and $0.013 \%$, respectively. After 36 months, the transfer rate of the exchange rate to import prices, producer prices, and consumer prices reached around 0.45 , 0.23 , and 0.13 , respectively.

From the above analysis, we can see that the transfer effect of nominal effective exchange rate of RMB on the domestic price level is not complete, and there is a certain time lag. The transfer rate of exchange rate in import prices is relatively large, at about 0.45 .

\subsection{Variance Decomposition Based on Vector Error Correction Model}

Next, we further use variance decomposition to empirically study the contribution of each variable shock to the interpretation of domestic price fluctuations.

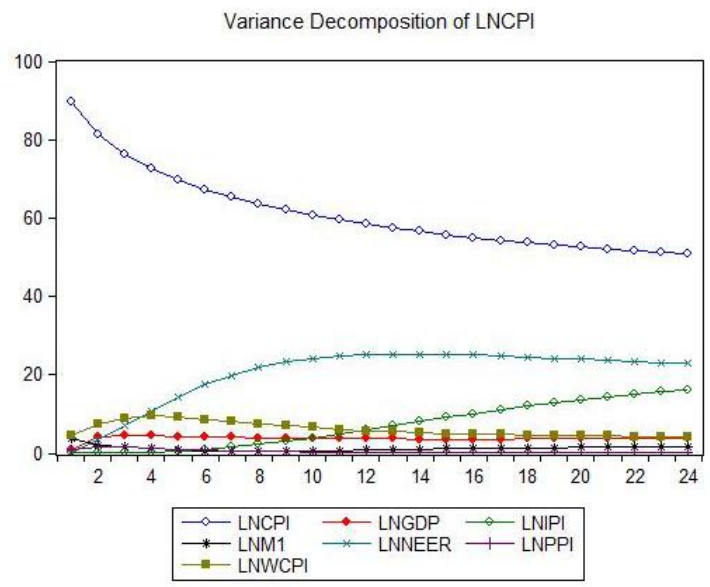

Figure 2. Variance decomposition of CPI

Figure 2 shows the variance decomposition results of the consumer price index. It can be seen from the figure 
that the main reason for the fluctuation of the consumer price index is self-impact, which can explain the change of the consumer price index over $50 \%$ in the long term. The impact of the exchange rate shock is relatively large, reaching 25.165 percentage points at 12 months, and it can be stable at over 20 percentage points over the long term. The impact of demand shocks on consumer price index changes is less, and the maximum number was only 4.569 percentage points. The supply shock reached 3.660 percentage points in the first period, and then continued to decline. The currency shock continued to decrease after reaching 9.425 percentage points in the fourth period.

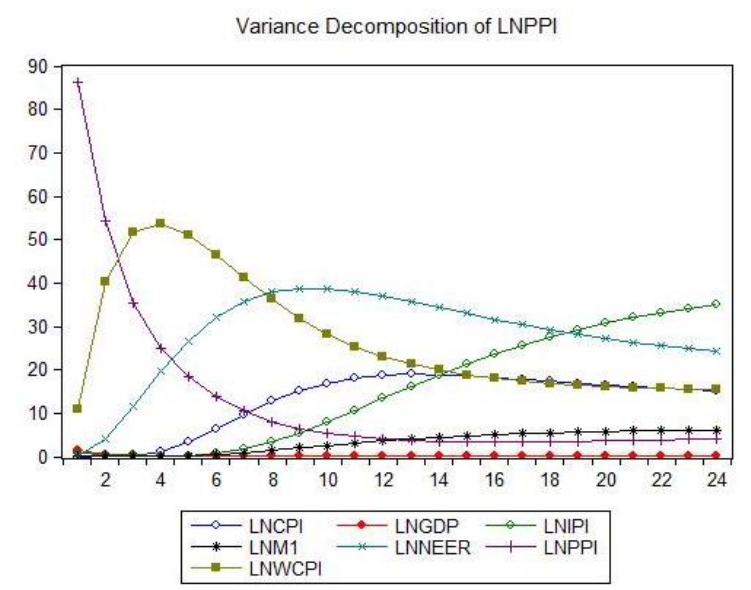

Figure 3. Variance decomposition of PPI

Figure 3 shows the variance decomposition results of the producer price index. It can be seen from the figure that for the fluctuation of the producer price, the explanation from the supply shock is stronger. By the fourth month, the supply shock can explain about $54 \%$ of the producer price. In addition, the exchange rate shock can explain up to $35 \%$ of producer price changes, while the impact of import prices and consumer price can explain the changes in producer prices by $15 \%$ and $35 \%$, respectively. Currency shocks can explain changes in producer prices by $6.1 \%$. The explanatory power of demand shocks is weak.

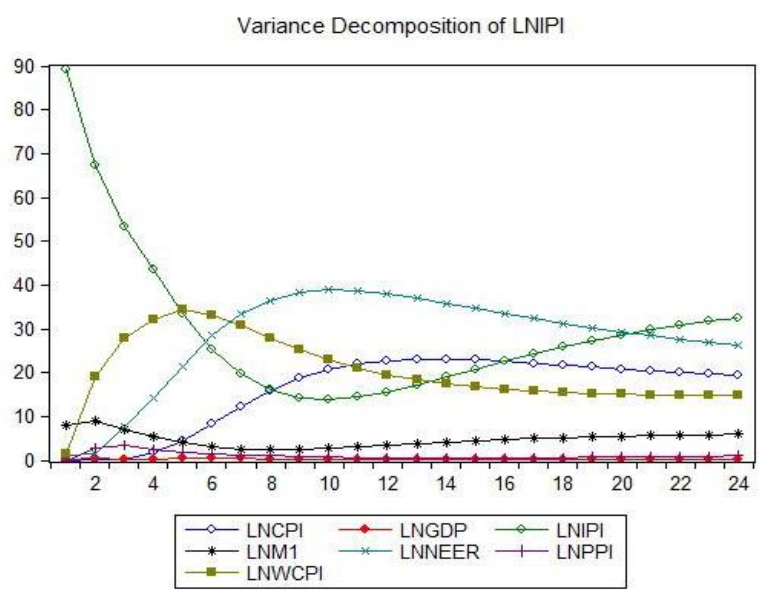

Figure 4. Variance decomposition of CPI

Figure 4 shows the variance decomposition results of the import price index. It can be seen from the figure that for the change of import prices, the exchange rate shock and the supply shock are relatively strong explanation, and the maximum can explain about $38 \%$ and $32 \%$ of the consumer price changes, respectively. The impact of consumer prices has a 13\% explanation for the change in import prices, while the explanatory power of currency shocks, producer price shocks, and demand shocks is weak. 
Table 7. Variance decomposition results for each price index

\begin{tabular}{ccccccccc}
\hline \multirow{2}{*}{ Index } & Shock source & \multicolumn{7}{c}{ Forecast period (month) } \\
\cline { 3 - 9 } & & 1 & 4 & 8 & 12 & 16 & 20 & 24 \\
\hline \multirow{4}{*}{ CPI } & CPI & 89.805 & 72.472 & 63.486 & 58.430 & 54.997 & 52.583 & 50.970 \\
& GDP & 1.047 & 4.569 & 3.863 & 3.642 & 3.617 & 3.639 & 3.669 \\
& IPI & 0.133 & 0.334 & 2.229 & 5.956 & 10.107 & 13.622 & 16.210 \\
& M1 & 3.633 & 1.102 & 0.491 & 0.780 & 1.187 & 1.502 & 1.708 \\
& NEER & 0.023 & 10.857 & 21.898 & 25.165 & 25.010 & 23.940 & 22.834 \\
& PPI & 0.771 & 1.242 & 0.480 & 0.246 & 0.209 & 0.260 & 0.340 \\
& WCPI & 4.587 & 9.425 & 7.553 & 5.780 & 4.874 & 4.455 & 4.270 \\
& CPI & 0.000 & 1.172 & 12.763 & 18.705 & 18.243 & 16.495 & 15.040 \\
& GDP & 1.425 & 0.146 & 0.231 & 0.116 & 0.082 & 0.064 & 0.053 \\
& IPI & 0.843 & 0.205 & 3.348 & 13.487 & 23.655 & 30.671 & 35.013 \\
& M1 & 0.128 & 0.170 & 1.388 & 3.615 & 5.015 & 5.760 & 6.176 \\
& NEER & 0.275 & 19.630 & 36.847 & 35.942 & 31.625 & 27.201 & 24.148 \\
& PPI & 86.322 & 25.042 & 8.108 & 4.063 & 3.388 & 3.644 & 4.053 \\
& WCPI & 11.007 & 53.635 & 36.315 & 23.072 & 17.991 & 16.164 & 15.517 \\
& CPI & 0.000 & 1.807 & 15.808 & 22.768 & 22.576 & 20.845 & 19.345 \\
& GDI & 0.164 & 0.273 & 0.325 & 0.173 & 0.130 & 0.104 & 0.090 \\
& IPI & 89.279 & 43.653 & 16.012 & 15.579 & 22.536 & 28.549 & 32.514 \\
& M1 & 7.944 & 5.292 & 2.449 & 3.519 & 4.704 & 5.439 & 5.875 \\
& NEER & 1.208 & 14.118 & 36.499 & 37.953 & 33.449 & 29.254 & 26.253 \\
& PPI & 0.000 & 2.589 & 0.982 & 0.538 & 0.496 & 0.750 & 1.044 \\
& WCPI & 1.404 & 32.268 & 27.924 & 19.471 & 16.110 & 15.060 & 14.880 \\
\hline
\end{tabular}

Table 7 shows the variance decomposition results of the three major price indices for 1 to 24 months. From the result of variance decomposition, we can see that exchange rate shocks have the strongest explanations for the changes in import prices, and they can explain 38\% of the change in import prices to the greatest extent. For producer prices, the explanation is slightly weaker, which can explain $37 \%$ of the change in the producer's price. It has the lowest ability to explain changes in consumer prices which it just can explain $25 \%$ of changes in consumer prices. Therefore, the impact of fluctuation of the nominal effective exchange rate of RMB along the price chain is gradually reduced.

\section{Conclusions and Recommendations}

Based on the economic theory of "exchange rate-price level" conduction, this paper constructed a five-variable basic model of exchange rate for a single price, and then conducted impulse response and variance decomposition analysis. The main conclusions are:

First, the impact of the fluctuation of the nominal exchange rate of RMB on domestic price level is incomplete and has a certain time lag. Import prices reacted most quickly to changes in exchange rates, while producer prices and consumer prices reacted in a slower manner. After 36 months, the rate of exchange rate changes in import prices, producer prices, and consumer prices reached $0.45,0.23$, and 0.13 , respectively. The impact of the nominal effective exchange rate of RMB on consumer prices is significantly weaker than the producer price, and the transmission effect on producer prices is significantly weaker than the import price.

Second, in the variance decomposition results of consumer prices index, producer prices index, and import prices index, most of the changes of consumer prices are caused by inertia itself. The contribution of nominal effective exchange rate of RMB shocks reached the maximum in the 12th month, about 25 percentage points. The interpretation of the impact of nominal effective exchange rate of RMB on the producer prices index and import price index changes is relatively strong, and the maximum value can reach 35 and 38 percentage points, respectively. It can be seen that the impact of fluctuation of the nominal effective exchange rate of RMB along the price chain is gradually reduced.

Thirdly, from the results of the cointegration test, it can be seen that exchange rate fluctuations are smooth to the transmission of a single price index, while exchange rate movements along the domestic price chain are incomplete. Every 1 unit drops of the effective exchange rate of RMB, the domestic consumer price index will fall 0.18 units. The error correction coefficient of the consumer price index is 0.0413 , which indicates there is a self-correcting dynamic mechanism of the "exchange rate-price level" transmission effect ranging from 
short-term fluctuations to long-term equilibrium.

Based on the above conclusions, we can see that since the exchange rate has a large transmission rate for import prices, it is still feasible to adjust China's trade balance by changing the exchange rate of the RMB so as to use the effect of expenditure conversion, but there is a time lag to use the exchange rate of RMB to mediate the trade revenue and expenditure and the size of the exchange rate conversion effect depends on the demand elasticity of imports. Therefore, we must dynamically look at the impact of exchange rate changes on trade balances. Due to the difference in exchange rates of exchange rates on different prices in the domestic price chain, the impact of exchange rate changes on different price indices should be taken into account when formulating policies. In addition, the appreciation of the RMB exchange rate after "exchange reform" has made a significant contribution to reducing domestic inflation. Therefore, to a certain extent, accelerating the appreciation of the RMB exchange rate is an effective way to reduce domestic inflationary pressures. In addition, controlling the growth of China's money supply is also an effective way to reduce consumer prices.

\section{References}

An, L., \& Wang, J. (2012). Exchange rate pass-through: Evidence based on vector autoregression with sign restrictions. Open Economies Review, 23(2), 359-380. https://doi.org/10.1007/s11079-010-9195-8

Auer, R. A. (2015). Exchange Rate Pass-Through, Domestic Competition, and Inflation: Evidence from the 2005-08 Revaluation of the Renminbi. Journal of Money, Credit and Banking, 47(8), 1617-1650. https://doi.org/10.1111/jmcb.12286

Engle, R. F., \& Granger, C. W. (1987). Co-integration and error correction: Representation, estimation, and testing. Econometrica: Journal of the Econometric Society, 251-276. https://doi.org/10.2307/1913236

Faruqee, H. (2004). Exchange rate pass-through in the euro area: The role of asymmetric pricing behavior (No. 2004-2014). International Monetary Fund. https://doi.org/10.5089/9781451843156.001

Feenstra, R. C. (1989). Symmetric pass-through of tariffs and exchange rates under imperfect competition: An empirical test. Journal of international Economics, 27(1), 25-45. https://doi.org/10.1016/0022-1996(89)90076-7

Ghosh, A. (2013). Exchange rate pass through, macro fundamentals and regime choice in Latin America. Journal of Macroeconomics, 35, 163-171. https://doi.org/10.1016/j.jmacro.2012.09.001

Goldberg, P. K., \& Knetter, M. M. (1996). Goods prices and exchange rates: What have we learned? (No. w5862). National Bureau of Economic Research. https://doi.org/10.3386/w5862

Guoming X., \& Qingfang, S. (2014). The impact of RMB exchange rate fluctuations on China's price levels: A perspective of exchange rate regime changes. Research in Finance and Trade, 25(4), 130-138. https://doi.org/10.19337/j.cnki.34-1093/f.2014.04.016

Hahn, E. (2003). Pass-through of external shocks to euro area inflation.

Hailin Y. (2010). Empirical analysis of the impact of RMB exchange rate changes on China's price level. Suzhou: Suzhou University.

Jun C., \& Xiaosen G. (2011). An empirical study on the impact of RMB exchange rate fluctuations on China's price levels. Journal of Capital University of Economics and Business, (3), 20-27. https://doi.org/10.13504/j.cnki.issn1008-2700.2011.03.010

Kim, K. H. (1998). US inflation and the dollar exchange rate: A vector error correction model. Applied Economics, 30(5), 613-619. https://doi.org/10.1080/000368498325606

Koop, G., Pesaran, M. H., \& Potter, S. M. (1996). Impulse response analysis in nonlinear multivariate models. Journal of econometrics, 74(1), 119-147. https://doi.org/10.1016/0304-4076(95)01753-4

Liang, S. H. I. (2016). Research on the Impact of the Fluctuation of RMB Exchange Rate on China's Import and Export Trade. DEStech Transactions on Social Science, Education and Human Science, (icss), 832-839. https://doi.org/10.12783/dtssehs/icss2016/9093

Marazzi, M., \& Sheets, N. (2007). Declining exchange rate pass-through to US import prices: The potential role of global factors. Journal of International Money and Finance, 26(6), 924-947. https://doi.org/10.1016/j.jimonfin.2006.12.003

Marston, R. C. (1990). Pricing to market in Japanese manufacturing. Journal of International Economics, 29(3), 217-236. https://doi.org/10.1016/0022-1996(90)90031-G 
McCarthy, J. (2000). Pass-through of exchange rates and import prices to domestic inflation in some industrialized economies. FRB of New York Staff Report, (111). https://doi.org/10.2139/ssrn.249576

Pesaran, H. H., \& Shin, Y. (1998). Generalized impulse response analysis in linear multivariate models. Economics letters, 58(1), 17-29. https://doi.org/10.1016/S0165-1765(97)00214-0

Razafindrabe, T. M. (2016). A multi-country DSGE model with incomplete exchange rate pass-through: An application for the Euro-area. Economic Modelling, 52, 78-100. https://doi.org/10.1016/S0165-1765(97)00214-0

Sekine, T. (2006). Time-varying exchange rate pass-through: Experiences of some industrial countries. https://doi.org/10.2139/ssrn.892508

Sheng, W., \& Tao, T. (2015). Analysis of the effect of RMB exchange rate on CPI transfer: Based on the perspective of mean and volatility Spill. International Finance Research, (4), 87-96. https://doi.org/10.16475/j.cnki.1006-1029.2015.04.009

Wei, C., Hao, L., \& Shengjun, D. (n. d.). Empirical analysis of the impact of RMB exchange rate transmission on China's price level: 2005 2008. World Economic Research, (4), 25-31; 87-88.

Yongxiang, B. (2001). The Impacts of China's Exchange Rate on Domestic Price. Journal of Finance, 3(2), 78-88.

\section{Note}

Note 1. For more information of the vector error correction model (VECM), please refer to: Tiemei G. et al. (2009). Econometric analysis methods and modelling: EViews applications and examples (Second Edition). Beijing: Tsinghua University Press.

\section{Copyrights}

Copyright for this article is retained by the author(s), with first publication rights granted to the journal.

This is an open-access article distributed under the terms and conditions of the Creative Commons Attribution license (http://creativecommons.org/licenses/by/4.0/). 